4th Global Business Research Congress, May 24-25, 2018, Istanbul, Turkey.

\title{
COST REDUCTION STRUGGLES IN SISTER COMPANIES
}

\author{
DOI: 10.17261/Pressacademia.2018.849 \\ PAP- V.7-2018(2)-p.11-17
}

\section{Burcu Birol}

Yeditepe University, Inönü Mah. Kayışdağı Cad. 326A, 26 Ağustos Yerleşimi 34755 Atasehir, Istanbul. burcubirol@yahoo.com, ORCID: 0000-0002-6113-1544

To cite this document

Birol, B. (2018). Cost reduction struggles in sister companies. PressAcademia Procedia (PAP), V.7, p.11-17.

Permemant link to this document: http://doi.org/10.17261/Pressacademia.2018.849

Copyright: Published by PressAcademia and limited licenced re-use rights only.

\begin{abstract}
Purpose- Cost is always in top ranking issues from corporations to small enterprises. In order to accomplish cost reduction goals, the structure of cost must be well defined. What does cost reduction really mean, and why close follow up for cost items are needed should be the main questions of cost projects. This paper discusses the cost reduction concept, and its techniques, and develops a point of view for the sister companies. Intercompany transactions have many opportunities to utilize, and sister companies can be benefited from common functions.

Methodology- A systematic literature review is performed in this study in order to present the concept itself, and a conceptual type of study is followed for discussing cost reduction methodologies in sister companies.

Findings- According to findings of the study, especially for manufacturing sister companies, there are some opportunities for cost reduction as taking the advantage of organization structure, re-organizing the support functions, volume impact in fixed costs, increased bargaining power in purchasing function, and peer learning behaviors in quality and R\&D activities.

Conclusion- Sister companies gain the favor of intercompany transactions in cost reduction issues, and are creating synergy for the total success.
\end{abstract}

Keywords: Cost control, cost reduction, sister companies, manufacturing companies, intercompany transactions JEL Codes: D24, M11, M40

\section{INTRODUCTION}

Competitive work environment force companies to take measure on cost issues. Increasing price of a product is not a good solution for increase the earned margin no longer. Customers have more opportunities to buy a product, and always have a chance to find cheaper. Ten to twenty years ago, cheaper means less quality, but now, even cheaper products have enough quality compared to expensive ones. Sometimes, cheaper product can be higher in quality than the most expensive product. This can be possible by focusing cost margin, i.e. cost reduction struggle.

While decreasing sales prices, pegging the margin can be done via reducing the costs without waiving quality. There are many methodologies in literature about cost reduction, and they are practicing in business environment as well. Benchmarking, target costing, activity-based costing, lean production and lean manufacturing, kaizen costing, six sigma can be listed as cost control approaches applied in industries. Such kind of cost management systems enable companies to recognize and follow their cost items very closely, and take actions on correct processes in order to reduce.

Sister companies are subsidiary companies that have owned by the same parent company. They are structured even under a holding organization, or small group of companies. In cost issues, they have some opportunities to lialise, and realize projects for cost reduction.

Shared services approach is suitable for sister companies in cost reduction. Especially organization structures have many opportunities to utilize, and common work load can reduce the total work done. Shared support functions, increased volume impact in fixed costs, bargaining power in common purchasing activities, and peer learning behavior in production processes lead all sister companies to reduce their total costs.

\section{LITERATURE REVIEW}

\subsection{Cost Control - Cost Management Systems}

Cost control and cost reduction are always in the top issues of company agendas. There should be a long-term strategic approach in order to accomplish cost management goals. This approach should integrate competitive strategy, technological strategies, human resource management strategies, and organizational design considerations in order to construct a sustainable competitive advantage (Shields and Young, 1992). 
There is a three-level strategy approach for large multi-business corporations, which are corporate strategy as in the top level, business unit strategy as in the second level, and functional area strategies like marketing strategy, manufacturing strategy and financial strategy as in the third level (Hofer, 1975; Hofer and Schendel, 1978). Manufacturing strategy should be integrated with business unit and corporate strategies in order to catch the competitive advantage. Cost, quality, flexibility, and dependability are four dimensions that manufacturing strategy literature identifies (Buffa, 1984; Wheelwright, 1984). According to Ward et al. (1996), Niche Differentiation, Broad Differentiation, Cost Leadership and Lean Competitiveness are four configurations of the development in manufacturing strategy with business unit competitive strategies under the configuration approach (Daniel et al., 2011).

Cost management is incluencing cost and sales deliberately in order to increase the efficiency of the firm in a sustainable way. Cost planning, cost control, and cost management are the elements of this management to optimise the cost-benefit relationship. Analysis of cost occurrence, action planning, and action implementation are the instrumental functions of cost management, whereas the creation of a cost culture, and personal functions such as training in special skills are the structural functions (Günther and Gäbler, 2014).

Baldam et al. (2008) states that the process of transforming inputs to outputs contains a chain of activities that are different operations and if well designed, planned and controlled, all operations are open for improvement. It is obvious that quality costs money, but lack of quality costs a lot more money (Mourao, 2016)

Product planning and cost management are the strategic decisions in a company that are benefited from the new management accounting innovations in benchmarking, target costing, and/or activity-based costing ( $A B C)$ especially in general periodical recessions and high competitive intensity times (Himme, 2012).

According to Chenhall (2004), there is a positive association between the successful implementation of ABC management and attention to behavioral factors. He studies the role of conflict in the implemantation of activity-based costing. Himme (2010) has also an empricial descriptive study that results firms having a better top management commitment and more participation have a more successful cost management. Thus, focusing on behavioral variables in the implementation process of management accounting and cost reduction processes brings success respectively.

Activity-based costing is based on the idea that general manufacturing expenses arise from the compulsory processes of production and management operations. It can also be explained as an accounting information system that is used in order to analyze resources, operations, cost items, and their results in a company. $A B C$ defines the processes, trace the costs incurred in the process, and uses allocation keys and drivers to allocate actual costs on products. The keys reflect the activity consumptions (Unutkan, Ö., 2010).

With this perspective, $A B C$ is a part of total quality management concept. Activity-based strategic planning and organization is integrated with cost management system. As an improvement tool, $A B C$ in process planning brings long-term financial success based on its activitybased structure and suits well to the customers' point of view (Yıldıztekin, 2011).

U. Diefenbach et al. (2018) developed a concept of cost management control systems that consists of five elements that can be influenced by management: strategy, organisation, information, methods, and culture; based on the management control research framework of Herath (2007). They used a sample of 251 European companies, and considered external context factors which can affect cost efficiency as control variables. According to their results, for creating a cost management control system, and enabling its effects on efficiency and performance, it is necessary and beneficial to create a corporate culture that supports cost-conscious behaviour and the right set of cost management methods.

Lean Production and Lean Manufacturing with their tools to manage and operate the system of production have their own rationalization of operations philosophy. The set of tools and techniques as instruments providing operating conditions support the philosophy (Mourao, 2016).

Zhou (2016) worked on small and medium-sized enterprises (SMEs) in the U.S. in order to understand their lean practices. Majority of the firms that apply lean has the objective of costs savings, continuous improvement, and waste reduction. The results demonstrate that most of the firms have a relatively good understanding of lean concept and philosophy.

The lean concept was seen in 1960s first. With the "origin" of lean as Japanese automobile manufacturer Toyota first introduced and implemented the Toyota Production System (TPS) (Krafcik, 1988).

The sigma level is the clear parameter for comparison and company positioning within competitors in the Six Sigma methodology. In statistical perspective, sigma is a measure of the variation of process equivalent to the standard deviation (Klefsjo et al., 2001). By measuring the size of the opportunities that a company has, its possible economical extent can be seen with its sigma level. Successful companies normally locate below 4 in sigma standard (Harry,2000).

There are cost reduction opportunities in supply chain management. Recognizing the supply chain management efficiencies very well leads the identification of should-cost opportunities. In this perspective, the context of "three Vs" is applied as a process-focused Should-Cost efforts:

First " $v$ " is Velocity, and it is related with time. How fast will be the procurement finalized is the main question. Just-in-Time (JIT) inventory management, and lean supply chains emphasize the flow. Second " $v$ " is Visibility, which means the traceability of supply chain data at any time and any point. Technologies such as Radio Frequency Identification (RFID) and Item Unique Identification (IUID) can be used to provide the data to reduce inventory levels and improve the supply chains' efficiency and cost effectiveness. Manufacturing Resources Planning and Enterprise Resource Planning applications are another tools for better understanding the resource needs. Last " $v$ " is Variability; and answer the question of how robust the supply chain is. How will the supply chain be react to fluctuations in demand? 
Finding new options for supplying inventory rather than holding large amounts of spares can be a significant saving (Sherman and Kobren, 2017).

Lean manufacturing (LM) also leads better productivity and brings benefits in production flowing. It has the principle of flexibility, and pace in response to the product and service requests. LM aims to increase the efficiency of the process chain, and so adding value to products and services. It is a successful production model for productivity and competitiveness since it enables the cost reduction and hence increase the profit (Todorut et al., 2016).

As a business strategy lean is used for improving the quality, eliminating waste and reducing time and costs. This leads overall organizational effectiveness. Thus, lean manufacturing improves profit margin, utilization of plant/facility, and maintain competitive position. It is an operational practice that has a target of elimination. The main goal of lean is improving the quality and service; poor quality products and defects are considered as waste (Holweg, 2007).

According to Womack and Jones (1994), in lean production, the relationship among different functional areas as research and design, engineering, human resources, marketing, and information technology should be fully understood and analyzed in depth. Cua et al. (2001) has studied the key elements of lean, and investigated the relationship between implementation of Total Quality Management (TQM), Just-in-Time (JIT), and manufacturing performance. Shah and Ward (2003) had the study of measurement for lean manufacturing analyzing the practices related to quality management, total preventive maintenance, and human resource management. Moreover, Achanga et al. (2006) stated that the success of lean implementation depends on four areas as leadership and management, finance, skills and expertise, and supportive organizational culture of the organization. On the other hand, Panizzolo (1998) divided the lean practice into six areas which are process and equipment; manufacturing, planning, and control; human resources; and product design (internal oriented lean practices), and supplier relationship and customer relationship (external oriented lean practices).

There are variety of different lean tools such as value stream mapping (VSM), workplace organization (5S), changeover reduction (SMED), quality certifications (e.g. ISO), Kaizen, and Pull/Kanban, and they are useful tools under different circumstances. These tools and techniques should be used in an integrated way in order to get successful results (Liker, 2004). Furthermore, management support plays a vital role in the accomplished lean implementation (Worley and Doolen, 2006).

Value added activities on products increase the total value of product and service, on the other hand; non-value added activities increase time consumed for production unless increasing the total value. Non-value added activities are redundant from the viewpoint of customers. These cost increasing activities are waste, and companies should get rid of them according to full-time production philosophy (Yıldıztekin, 2011)

Lean production is also the identification and elimination of non-value added processes. Material or information being stored, inspected, delayed, waiting in queues, and defects/errors do not add values. Thus, lean is the way for improving quality, eliminating waste, reducing time and total cost. The main goal is providing products and services that can satisfy customer demands with no waste (Holweg, 2007).

Target costing as a Japan management philosophy, is a costing method enables companies to understand the production processes, allocation of costing and costing information, its reliability, and significance in decision making process. This approach improves the timing, convenience, context, and quality of the costing information used in long-term strategies. Rapid improvements in technology, changing customer demands, diminished product life-cycles, and increased fixed costs lead developments in target costing as a more strategic, fast, and beneficial knowledge generation tool (Kurşunel, 2005).

Market orientation, early cost management and cooperative efforts are main characteristics of target costing (Ahn et al., 2018). Firstly, market cost information should be collected as a central role for cost-efficient product development (Everaert and Swenson, 2014). Secondly, early cost management should be applied in the product development phase, and thirdly; a cooperative effort is needed from different business areas in order to achieve challenging target costs (Everaert et al., 2006).

As a substitute to target costing, kaizen costing is constructed with its internal focus to the market perspective. Addition to new launches, kaizen contributes to cost reduction in market phase for already existing products. Thus, kaizen costing is also suitable for the products whose functionality is already defined and cannot be changed easily (Ahn et al., 2018). According to Cooper (1996), kaizen costing activities can may have an influence only approximately $10 \%$ of a product's costs, on the contrary to approximately $90 \%$ influence in target costing based on the results of limited influence on product design.

There are two main fields in the application of kaizen costing. First one is the concept of steady cost optimization, and the second one is the application for a product that is already introduced in the market due to strategic reasons. This means there is a standard cost, and it is below the target cost, but kaizen costing aims to reduce the level of standard costs (Ahn et al., 2018).

Brunet and New (2003) worked on 11 Japanese steel and automotive companies in order to observe the kaizen contribution of personnel. According to their study, firms have kaizen established targets for work teams, and team members are expected to use kaizen for achieveing the targets. There are long-term motivational packages to encourage employees for their contribution, and various reward and incentive systems are used in kaizen costing approach.

Daniel et al. (2011) studied the effect of time horizon and the verifiability of the worker's acquired skill level on three concepts which are the choice of standards, the induced investment in skill-acquisition activities, and the worker's cost-reducing effort. For cost-reducing efforts they conclude that if the worker's acquired skill remains unchanged, he chooses increasingly less demanding cost targets and to expend less cost-reducing effort over time. 


\subsection{Sister Companies and Shared Services}

Sister companies are subsidiary companies that have owned by the same parent company. They can either be interdependent, and/or being a part of a holding structure. Such companies can produce the same or similar products, as well as different product types. Regardless of their product line, they can be serve to the same market or not. They can make sell and buy transactions from one to another, and sometimes, they can be even competitors. Each sister company is independent of the other sister companies, and there is a special pricing policy among them in such transactions, and subject to Transfer Pricing Policies.

Especially in support services, shared services concept is a new and hot topic in the literature as well. The main reason behind such integration is cost reduction. Curry (1976) introduced the partial use of shared buying in the US health sector, as an example of shared services (Ahmed, 2016). Seal and Herbert (2013) conducted a case study that is exploring the concept of finance shared service centers within a multi-divisional organization. In the transformation process of finance function, they stated that the management accounting systems are changed, and made stable by shared service centers. As a result, reconstruction of finance funtion is a rational response to cost reduction, and efficiency gains.

Sterba \& Grechenig (2009) studied on six case studies in information technology (IT) shared service industry, and examined the implementations on Information Services cost optimization. In case organizations, differences exist in management expectations before and after shared service applications. Although there are some implemantation cost issues, the involvement of staff issues, and a possibility of fail or success, it is argued that the consolidation of information systems services will be beneficial.

Ulbrich \& Borman (2012) worked on a framework to predict when unbalanced process standardization leads to less effective service delivery modes in shared services. These unbalance process standardization which can be deteceted in centralized shared services, outsourcing shared services, colloborative shared services, and decentralized shared services negatively affect the goals of cost reduction and quality improvements. The paper also states that process standardization brings benefits in shared services implementations.

\section{COST REDUCTION PROJECTS IN SISTER COMPANIES}

Although cost reduction projects are always in the agenda of every company, sister companies have more opportunities to accomplish such cost targets. Especially in manufacturing industry, there are many open issues for cost projects, and the structure of companies give opportunities to the management team for successful projects.

There are important elements that should be well-defined before constructing a cost reduction project in sister companies. Location of companies / plants, product types, production versions, and human resources of each company should be analyzed beforehand, and be reported objectively.

Companies that have same products or similar production processes have advantages in cost reduction projects. There are improvement areas for both fixed and variable cost items. In the case of different production processes, project team should focus on fixed costs for reduction.

Production starts with raw materials, and the highest percentage of production cost comes from raw material costs. Sister companies can be benefited from the supply of raw material from common suppliers with increased purchase volume. Suppose one plant consumes 1 unit material and the sister plant consumes 2 units, rather contracting separately, companies can gain a bargaining power with total 3 units of purchase.

Other materials that are used in production process, and also chemical consumables have same cost reduction opportunity. Spare part purchases also subject to similar bargaining power. If processes are same or very similar, machines in production are expected to be same. Thus, similar spare parts can be purchased in discounted lower prices with increased volume effect.

Not only bargaining power, but also time consumed for purchasing activities of raw materials, consumables and basic spare parts saved with common supplying. Moreover, there is a saving in man power for purchasing.

On other side of coin, increased volume in purchased material make the sister companies loyal and big customer in the eyes of the suppliers. Thus, they will try to avoid losing both companies, and this creates a high service quality customer profile.

In the production activities, especially sister companies that producing same products can divide and group the processes of production as a cost reduction strategy. For instance, half products can be produced by one plant, and other plant can get the work-in-process materials and continue to construct the final - packed - product. This leads more focusing while reducing process steps per plant. Experienced man power can be more focused, and lean production reduces total cost of sister companies.

On the other hand, there are important questions that need answers in sectional production. The plant producing half product (Plant A) will be the supplier of other plant (Plant B) producing final packed product. In this case, will plant B have other suppliers rather than plant $A$ as backup? On the contrary, will plant $A$ have other customers rather than plant B? Should they need other potential customers and suppliers? Any negative scenarios in each plant can directly affect the production process of the sister company. These cases could be quality problems, missing the deadlines due to some other reasons, legal constraints or threats, or strike possibilities. How will be the sister company effected in crisis cases? How will this affect the final product customer as chain reaction? Is there any possiblity to loose the customer?

Furthermore, transfer pricing issues must be reviewed carefully, and the final decision should be made after all those questions are answered in detail. While aiming cost reduction, the management should not allow serious losses. Although there are opportunities for reduction, management team could decide keeping separate full production for both companies in order to reduce total risk. However, if 
all scenarios can be solidly analyzed and constructed, there is a great opportunity in sectional production for cost reduction in sister companies.

Another opportunity area is in labor cost. The synergy that created in man power provides opportunities for direct labor in production with positive manner as well as indirect labor. Especially, a simplification can be applied in support functions. Shared purchasing, sales, marketing, finance, accounting, information technologies, and human resources departments can be constructed that serving all sister companies. By performing integration in organization, repeated jobs can be eliminated, and support functions with new way of working can be served to all producing plants, and head quarter.

Number of people recruited can be under control with merger; this does not mean firing people from mentioned companies, but constructing optimum man power in one department for all plants. Assume you have two companies, and each company has four people working in human resources department. Six personnel could be optimum for the work done totally in one team with synergy. Cost reduction opportunities in man power should be analyzed carefully.

Other cost reduction opportunity in support functions is to separate jobs based on experiences of people. In purchasing department, main raw material purchases can be done by one or two qualified personnel, service purchases can be done by one person, and other purchases such as spare parts, office supplies etc. can be done by other people in the department. With shared purchasing, there will be enough man power to differentiate and categorize the work items.

Sister companies that producing the same or similar products have also an opportunity in direct labor. If necessary, workers can be assigned in more than one function and with their expertise, new cost reduction areas can be created.

Shared outsourcing activities are another opportunity to reduce total costs of sister companies. Common contracts can be made with consulting, auditing firms, and law services. This increases the bargaining power due to reaching an agreement for more than one company. This is valid for nearly all service suppliers. Shared catering, personnel transport, and security services are opportunities for getting better in cost reduction.

There is also a volume impact in the bargaining process of transportation issues of goods. The highest work load means the highest possibility of discount from the transporter. This makes sister companies one bigger and irreplaceable customer in the eyes of supplier.

In the improvement process of products, more than one company can work more efficiently, and can direct more of their resources effectively. Especially in production, scrap and losses are important problems. More ideas can be created and stop loss actions can be taken in synergy. The projects that are costly for only one company can easily be conducted in sister companies. Total cost of the project can be allocated with an appropriate allocation key. With this method, total benefit will be earned by both companies and cost will be incured in reasonable amounts.

Same approach is applicable in laboratories. Quality tests need expensive investments in companies. Especially sister companies that have location advantage can be benefited from shared lab service. Existing laboratories can be divided into their expertness, such as chemical lab, metallurgical lab, mechanical lab, and etc.

Finding new customers, and reaching new markets is another cost reduction methodology. This leads increase in production, and so, fixed costs will decline. The ultimate purpose should be working on full capacity, because idle capacity i.e. machines not working returns as cost. The simplest cost reduction way is increasing the production volume especially for fixed costs. Shared sales and marketing functions in sister companies can be worked with same approach on common goal for reaching new markets.

The synergy in sales and marketing function is valid also for costly sales channels. Especially the usage of media, and - nowadays - social media is sometimes expensive for medium size companies. However, benefiting from shared marketing tools reduces total cost of sister companies. Holding companies have already used this way of working in advertisements. For instance; an ad of brand $\mathrm{X}$ washing machine suggests brand $\mathrm{Y}$ of detergent. A special and professional team that is composed from sister companies marketing personnel can promote for - social - media applications with low cost.

Furthermore, a shared planning function can help sister companies in reducing total costs. As mentioned before, idle capacity is directly related with cost increases, so providing big picture to the planning department helps them to reach the optimum capacity in each plant if they produce exactly the same product. Maximum capacity is the solution for the lowest fixed cost. In the case of one company working with full capacity, and the other with less results higher total cost, but finding the optimum production level with allocating to both companies enable them to make money at the same time.

\section{CONCLUSION}

Cost control and management systems are the main assistants of management team in corporations for cost reduction projects. Recognizing, defining, and analyzing the cost items before setting reduction goals enable to come a long way in cost savings.

There are many techniques in cost follow-up such as benchmarking, target costing, activity-based costing, lean production and lean costing, kaizen costing, and six sigma, and these techniques are already and widely used by many companies in the industry. By applying these concepts in production, waste parts are eliminated, product designs are optimized, and costs are held under control.

Sister companies have many opportunities in cost reduction projects due to their structure. They are subsidiary companies that have owned by the same parent company. For especially manufacturing sister companies with same production line, common functions that are constructed with shared organization helps them to control their total cost. Shared purchasing, planning, finance and accounting, human resources management, and sales and marketing departments can create synergy in man power, and reduce labor cost. Due to total volume impact, a bargaining power arise in all supplied resources. 
Moreover, sister companies have advantage on cost allocation of bigger cost reduction projects. High-costly research and development activities, improvements in quality processes, and expensive marketing channels can be applied, and total cost can be split and allocated based on previously determined keys.

Shared services provide an opportunity to be specialized on job, and people can get experience only focusing their own division. Capacity optimization is another advantage of shared services. Both in man power, and in production planning, resources can be used in most optimum level.

As a limitation, this study focuses on the manufacturing sister companies that are producing exactly the same or similar products. Cost reduction opportunities in other sister companies that have different product portfolios can be examined in further researches.

\section{REFERENCES}

Achanga, P., Shehab, E., Roy, R., Nelder, G. (2006). Critical success factors for lean implementation within SMEs. Journal of Manufacturing Technology Management, 17, 460-471.

Ahmed, R. (2016). Shared services and cost reduction in government organizations: a synthesis. Allied Academics International Internet Conference, Vol. 18, No. 2, p. 33-38.

Ahn, H., Clermont, M., Schwetschke, S. (2018). Research on target costing: past, present and future. Management Review Quarterly, 1-34. https://doi.org/10.1007/s11301-018-0141-y

Altınbay, A. (2006). Kaizen maliyetleme sistemi: dinamik bir maliyet yönetimi sistemi. Afyon Kocatepe Üniversitesi, i̇.i.B.F. Dergisi Cilt. VIII, Sayı.1, s. 103-121.

Baldam, R., Valle, R. Silva, H. P. da. (2008). Gerenciamento de processos de negócios: BPM - Business Process Management. 2. ed. Sao Paulo: Erica.

Brunet, A. P., New, P. (2003). Kaizen in Japan. International Journal of Operations Management 23(12): 1426-1446.

Buffa, E. S. (1984). Meeting the competitive challenge. Homewood, IL: Dow Jones-Irwin.

Chenhall, R. H. (2004). The role of cognitive and affective conflict in early implementation of activitybased cost management. Behavioral Research in Accounting, 16, 19-44.

Cua, K., McKone, K., Schroeder, R. G. (2001). Relationships between implementation of TQM, JIT, and TPM and manufacturing performance. Journal of Operations Management, 19, 675-694.

Curry, W. (1976). How hospitals are controlling costs. Trustee, 29(6), 18-20, 29.

Cooper, R. (1996). Lean enterprises and the confrontation strategy. Academy of Management Executive 10(3):28-39

Daniel, S., Lee, D., Reitsperger, W., and Morse K. (2011). Implementation of Japanese manufacturing strategies through management control systems. Asian Business and Management 10(1), 37-65.

Diefenbach, U., Wald, A., Gleich, R. (2018). Between cost and benefit: investigating effects of cost management control systems on cost efficiency and organisational performance. Journal of Management Control 29, 63-89

Ertaş, F. C. (1999). İşletmelerde maliyet düşürme yaklaşimı: Kaizen (sürekli iyileştirmeye yönelik) maliyetleme yöntemi. İktisadi İdari Bilimler Dergisi, Cilt: 13, Haziran, Sayı: 1

Everaert, P., Loosveld, S., van Acker, T., Schollier, M., Sarens, G. (2006). Characteristics of target costing: theoretical and field study perspectives. Qual Res Account Manag 3(3):236-263.

Everaert, P., Swenson, D. W. (2014). Truck redesign case: simulating the target costing process in a product design environment. Issues Account Educ 29(1):61-85.

Günther, T. W., Gäbler, S. (2014). Antecedents of the adoption and success of strategic cost management methods: A meta-analytic investigation. Journal of Business Economics, 84(2), 145-190.

Harry, M. J. (2000). Abatement of business risk is key to Six Sigma. Quality Progress, 33, 72-76.

Herath, S. K. (2007). A framework for management control research. Journal of Management Development, 26(9), 895-915.

Himme, A. (2010). Cost management projects in Germany. Journal of Cost Management, 24(1), 24-32.

Himme, A. (2012). Critical success factors of strategic cost reduction, Results from an empirical survey of German cost reduction projects. Journal of Management Control, 23, 183-210.

Hofer, C. W. (1975). Toward a contingency theory of strategy. Academy of Management Journal 18(4): 784-810.

Hofer, C. W. and Schendel, D. (1978) Strategy formulation: Analytical Concepts. New York: West.

Holweg, M. (2007). The genealogy of lean production. Journal of Operations Management, 25, 420-437. 
Krafcik, J. F. (1988). Triumph of the lean production system. Sloan Management Review, 30(1), 41-52.

Kurşunel, F., Alkan, A. T., Büyükşalvarcı, A. (2005). Maliyet yönetiminde çağdaş bir yaklaşim: hedef maliyetleme. Sosyal Bilimler Meslek Yüksekokulu Dergisi, 8(1-2), 57-74.

Liker, J. K. (2004). The Toyota way: 14 management principles from the world's greatest manufacturer. New York: McGraw-Hill.

Mourao, F. de A. J., Magalhaes, E. M., Carjaval, T. L. R. (2016). Proposal of cost reduction in the produciton process of soft drinks concentrate from Tholor do Brasil based on the Use of integrated PDCA/DMAIC tools. Business Management Dynamics, Vol.6, No.1, Jul 2016, p.36-54.

Panizzolo, R. (1998). Applying the lessons learned from 27 lean manufacturers. The relevance of relationships management. International Journal of Production Economics, 55, 223-240.

Shah, R., Ward, P. (2003). Lean manufacturing: context, practice bundles and performance. Journal of Operations Management, 21, 129149.

Seal, W., Herbert, I. (2013). Shared service centres and the role of the finance function. Journal of Accounting \& Organizational Change, $9(2), 188-205$.

Sherman, M., Kobren, B. (2017). Product support should-cost opportunities O\&S strategies to boost affordability. Defense AT\&L: November-December 2017, p.3-9.

Shields, M. D., Young, S. (1992). Effective long-term cost reduction: a strategic perspective. Journal of Cost Management, 6(1), 16-30.

Sterba, C., Grechenig, T. (2009). Discrepancies between expectation and evaluation results of IS shared services. Paper presented at the 14th International Conference of the Association Information and Management 2009, AIM 2009.

Todorut, A. V., Paliu-Popa, L., Tselentis, V. S., Cirnu, D. (2016). Sustainable cost reduction by lean management in metallurgical processes. Metalurgija 55 (2016) 4. p. 846-848.

Ulbrich, F., Borman, M. (2012). Preventing the gradual decline of shared service centers. Paper presented at the 18th Americas Conference on Information Systems 2012, AMCIS 2012.

Unutkan, Ö. (2010). Faaliyet tabanli maliyet sistemi ve bir uygulama. Mali Çözüm, Sayı: 97-2010, s: 87-105.

Ward, P. T., Bickford, D. J., Keong Leong, G. (1996). Configurations of manufacturing strategy, business strategy, environment and structure. Journal of Management 22(4): 597-626.

Wheelwright, S. (1984). Manufacturing strategy: defining the missing link. Strategic Management Journal 5(1): 77-87.

Womack, J., Jones, D. T. (1994). From lean production to the lean enterprise. Harvard Business Review, 72, 93-104.

Yıldıztekin, İ. (2011). Maliyet kontrolü için faaliyet analizi. Atatürk Üniversitesi İktisadi ve İdari Bilimler Dergisi, Cilt: 25, Sayı: 3-4, s. 181-211.

Zhou, B. (2016). Lean principles, practices, and impacts: a study on small and medium-sized enterprises (SMEs). Annual Operational Research, 241, 457-474. 